\title{
SUPERVISI AKADEMIK KEPALA SEKOLAH SEBAGAI UPAYA MENINGKATKAN KINERJA GURU SDN O04 TOAPAYA DALAM PEMBELAJARAN DI KELAS
}

\author{
Rita Mardiani \\ SDN 004 Toapaya \\ Email: ritamardianisdn004toapaya
}

\begin{abstract}
This study aimed at improving the performance of SDN 004 Toapaya teachers in classroom learning through academic supervision at the second semester of the 2019/2020 academic year. The research subjects were teachers of SDN 004 Toapaya. The research was conducted in two cycles; each cycle consisting of four stages, namely: Planning, Implementing, Observing and Reflecting. The performance indicator set was if the score was at least 12 (sufficiently active). In classroom learning, it can be said that the actions taken are successful. Aspects measured in the observation are class teacher enthusiasm, teacher interaction with school supervisors, teacher interaction in KKG, group cooperation, and activities in group discussions. In the analysis, it was found that there was an increase in the activity and competence of teachers who compiled lesson plans from cycle I to cycle II. The achievement of performance indicators was achieved in the second action. Thus, it can be assumed that the Principal's Academic Supervision is an Effort to Improve the Performance of SDN 004 Toapaya Teachers in Classroom Learning. It is recommended to other supervisors or researchers that this teacher's improvement model is continued to be implemented on an ongoing basis.
\end{abstract}

Keywords: Principal Supervision, Teacher's Performance, Classroom Learning

\begin{abstract}
Abstrak
Penelitian ini bertujuan untuk meningkatkan kinerja guru-guru SDN 004 Toapaya dalam pembelajaran di kelas melalui supervisi akademik semester 2 tahun pelajaran 2019/2020. Subjek penelitiannya adalah guru-guru SDN 004 Toapaya. Penelitian dilakukan dengan dua siklus masing-masing siklus terdiri atas empat tahapan yakni: Perencanaan, Pelaksanaan, Observasi dan Refleksi. Indikator kinerja yang ditetapkan adalah bila minimal skor 12 (cukup aktif). Dalam pembelajaran di kelas maka sudah dapat dikatakan tindakan yang diterapakan berhasil. Aspek yang diukur dalam observasi adalah Antusiasme guru kelas, interaksi guru dengan pembilan pengawas sekolah, interaksi guru dalam KKG, kerja sama kelompok, aktivitas dalam diskusi kelompok. Dalam analisis diperolah bahwa terjadi peningkatan aktivitas dan kompetensi guru yang menyusun RPP dari siklus I ke siklus II. Ketercapaian indicator kinerja terdapat pada tindakan ke II. Dengan demikian, dapat diumpamakan bahwa Supervisi Akademik Kepala Sekolah Sebagai Upaya Meningkatkan Kinerja Guru-Guru Sdn 004 Toapaya Dalam Pembelajaran Di Kelas. Disarankan kepada pengawas atau peneliti yang lain agar model peningkatan guru ini tetap dilaksanakan secara berkesinambungan.
\end{abstract}

\section{Kata Kunci: Supervisi Kepala Sekolah, Meningkatkan Kinerja Guru-Guru, Pembelajaran di Kelas}

\section{PENDAHULUAN}

Perkembangan teknologi yang sudah menjamur diberbagai kalangan telah mengundang ketertarikan segenap masyarakat yang dipandang peneliti sebagai jembatan untuk menyalurkan berbagai macam hal, salah satunya adalah peningkatan kinerja guru-guru dalam pembelajaran .Apa yang disampaikan tersebut, setelah melakukan eksplorasi dari berbagai sumber yang merujuk pada Peraturan Pemerintah Republik Indonesia (RI) Nomor 19 tahun 2005 tentang Standar Nasional Pendidikan pasal 19 di jelaskan bahwa (1) Proses pembelajaran pada satuan pendidikan diselenggarakan secara interaktif, inspiratif, menyenangkan, menantang, memotivasi peserta didik untuk berpartisipasi ekiit, serta memberikan ruang yang cukup bagi prakarsa, kreativitas, dan kemandirian 
sesuai dengan bakat, minat, dan perkembangan tisik serta psikologis peserta didik; (2) Setiap satuan pendidikan melakukan perencanaan proses pembelajaran, pelaksanaan proses pembalajaran, penilaian hasil pembelajaran, dan pengawasan proses pembelajaran untuk terlaksananya proses pembelajaran yang efektif dan efisien.

Menyikapi keadaan yang demikian, sekolah sebagai salah satu institusi yang menyelenggarakan proses pendidikan memiliki tanggung jawab dan andil besar dalam menghasilkan produk sumber daya insani yang berkualitas harus terus mendapat perhatian. Salah satunya adalah melalui kegiatan supervisi yang baik dan tepat guna artinya penyelenggaraan pendidikan diperlukan adanya manajemen yang efektif.

Kinerja guru pada prinsipnya tercermin dari prestasi belajar siswa, apabila kinerja guru tinggi mempunyai dampak yang sangat kuat terhadap tingginya prestasi belajar siswa. Oleh sebab itu tuntutan kinerja guru menjadi lebih keras, karena dengan meningkatnya kinerja guru, maka prestasi belajar siswa juga akan meningkat, sehingga dapat meningkatkan mutu pendidikan secara keseluruhan. Supervisi berasal dari kata super yang berarti "diatas" dan vision berarti "melihat" maka secara keseluruhan supervisi berarti "melihat dari atas". Dari pengertian inilah supervisi diartikan sebagai kegiatan yang dilakukan oleh pengawas dan kepala sekolah sebagai pejabat yang berkedudukan di atas guru.

Supervisi dapat dibedakan atas dua jika dilihat dari konsep pengertiannya yakni : 1 . Supervisi akademik yang menitik berat pada pengamatan masalah akademik saat proses belajar. 2. Supervisi administrai yang menitik berat pada pengamatan aspek administrasi pendukung pelaksanaan pembelajaran.

Tujuan supervisi dapat dibedakan atas dua yakni: Tujuan umum dan Tujuan khusus. Tujuan umum berupa makna supervisi itu sendiri berupa bantuan teknis dan bimbingan kepada guru dan staf sekolah sedangkan tujuan khusus diarahkan pada kinerja komponen-komponen supervisi seperti siswa, guru ,dan staf lain, materi kurikulum, sarana dan prasarana, pengelolaan, serta lingkungan dan situasi umum.

Dari pengamatan di lapangan dapat diasumsikan bahwa supervisi kepala sekolah dapat berpengaruh terhadap kinerja guru.Oleh sebab itu peneliti mengajukan penelitian dengan judul : Supervisi Akademik sebagai upaya meningkatkan kinerja guru-guru SDN 004 Toapaya dalam pembelajaran di kelas semester 2 Tahun pelajaran 2019/2020. Penelitian ini mempunyai tujuan yakni:Meningkatkan Kinerja guru SDN 004 Toapaya dalam pembelajaran di kelas dan Meningkatkan Kinerja guru SDN 004 Toapaya setelah di supervisi oleh kepala sekolah.

Kinerja guru menurut Hamzah B.Uno (2008:15) mengatakan kinerja guru adalah semua kegiatan atau tingkah laku yang dialami tenaga pengajar, jawaban yang mereka buat untuk memberi hasil atau tujuan. Tinggi dan rendahnya kinerja guru tentunya sangat tergantung kepada faktor yang mempengaruhinya. Jones mengatakan bahwa banyak hal yang menyebabkan terjadinya kinerja yang buruk, antara lain dikarenakan: 1) kemampuan guru rendah. 2) Kemampuan kepala sekolah rendah. 3) Kesenjangan tinggi. 4) Masalah lingkungan tidak sehat.5) pribadi guru labil. 6) Guru motivasi rendah. Sehubungan banyak faktor yang diukur, maka penilaian kinerja guru sangat sensitif terhadap faktor-faktor tersebut. Uraian Teori kinerja tersebut dapat disimpulkan dari kinerja guru adalah hasil unjuk kerja yang telah dicapai guru atas standarisasi ukuran penilaian kerja dan sifat pribadi guru dalam mencapai tujuan

Pengertian tentang supervisi menurut Nawawi dalam kutipan Sagala supervisi mempunyai tujuan untuk menolong para guru dengan kesadarannya sendiri, sehingga dapat berkembang dan tumbuh menjadi guru yang lebih cakap dan lebih baik dalam menjalankan tugastugasnya. Sedangkan menurut Depdiknas supervisi kepala sekolah adalah supervisi/pembinaan yang menyangkut aspek administratif, bila pula menyangkut aspek teknis edukatif/akademik professional.

Fungsi utama supervisi ditujukan pada perbaikan dan peningkatan kualitas pengajaran. Menurut Briggs dalam Sahertian mengungkapkan bahwa fungsi utama supervisi bukan perbaikan pembelajaran saja tapi untuk mengkoordinasi, menstimulasi, dan mendorong kearah pertumbuhan profesi guru. Ada dua jenis supervisi yaitu supervisi validasi dan supervisi kunjungan kelas. Kedua jenis supervisi tersebut memiliki tujuan yang berbeda, yang satu lebih menekankan kegiatan di kelas sedangkan yang lain untuk proses evaluasi dari kinerja guru. Validasi adalah suatu istilah yang hampir sama dengan penilaian atau evaluasi. Sesama teman sebagai pihak luar yang melakukan sedangkan Supervisi kunjungan kelas merupakan pembinaan profesional yang dilakukan secara sistematik kepada guru dan calon guru dengan tujuan untuk membina keterampilan mengajar. Supervisi kunjungan kelas berupa kehadiran kepala sekolah ke dalam kelas.

Teknik dalam upaya mencapai tujuan supervisi dari kepala sekolah dapat mempergunakan teknik kelompok dan teknik individual. Teknik Kelompok yaitu kepala sekolah menganggap masalah yang dihadapiguru adalah sejenis, dan pemecahannya dapat dilakukan 
dengan teknik kelompok, seperti rapat kerja sekolah, lokakarya, penataran, seminar, diskusi dan sebagainya sedangkan Teknik Individual yaitu masalah yang dihadapi guru adalah masalah yang bersifat pribadi, dan teknik yang digunakan adalah teknik individu. Teknik individu merupakan sistem pendekatan personal yang akan berkembang menjadi hubungan interpersonal.

Supervisi dapat disimpulkan sebagai bentuk supervisi kepala sekolah adalah kegiatan kepala sekolah dalam membantu, membimbing dan membina guru melalui monitoring, pengawasan, dengan cara mengkoreksi kegiatan para guru yang kurang benar agar dapat meningkatkan kompetensinya. Pembelajaran di kelas menurut Robert F Mager dalam Hamzah B Uno adalah perilaku yang hendak dicapai atau yang dikerjakan oleh siswa pada kondisi dan tingkat kompetensi tertentu diruang belajarnya.

\section{METODE PENELITIAN}

Adapun lokasi penelitian ini di SD Negeri 004 Toapaya. Pihak sekolah sudah berupaya semaksimal mungkin agar lingkungan sekolah aman, nyaman, bersih sebagai upaya mendukung pelaksanaan pembelajaran sesuai harapan.

Penelitian Tindakan Sekolah ini menggunakan rancangan menurut Moleong mengungkapkan bahwa pelaksanaan penelitian meliputi yaitu:1)Tahap Perencanaan.Tahap ini meliputi kegiatan observasi awal ke lapangan penelitian dan permohonan izin kepada subyek yang diteliti dan pihak-pihak yang berkepentingan. Mempersiapkan lembar observasi, dan dokumentasi. Pada langkah perencanaan ini 2) Tahap Pelaksanaan.Tahap ini meliputi pengumpulan data-data melalui observasi dan supervisi tentang masalah penelitian.3)Tahap Refleksi meliputi menganalisa kekurangan/kelemahan dan aktivitas guru dan kelebihan/kekuatan dari masalah yang diteliti. Kemudian mengkolaborasikan dengan guru dan merencanakan perbaikan pada siklus berikut.

Adapun subjek penelitian ini adalah guruguru siswa SD Negeri 004 Toapaya pada Semester 2 Tahun Pelajaran 2019/2020

Objek penelitian yang peneliti upayakan dengan tindakan untuk mengatasi permasalahan yang akan diselesaikan adalah menggunakan Supervisi akademik sebagai upaya meningkatkan kinerja guru-guru SDN 004 Toapaya dalam pembelajaran di kelas semester 2 tahun pelajaran 2019/2020

Penelitian tindakan sekolah yang dilaksanakan di SD Negeri 004 Toapaya semester 1 Tahun Pelajaran 2019/2020 dilaksanakan dari bulan Januari sampai bulan Juni 2020
Teknik pengumpulan data yang digunakan dalam penelitian tindakan kelas ini adalah observasi dan dokumentasi.

Observasi dalam penelitian ini dilaksanakan dengan 2 (dua) teknik agar pengamat dalam hal ini peneliti mempunyai dua peranan sekaligus yaitu sebagai pengamat dan sekaligus menjadi anggota resmi dari kelompok yang diamati. Untuk mendukung keduanya maka peneliti melakukan observasi atau pengamatan yang didasarkan atas pengalaman secara langsung dan observasi atau pengamatan murni.

Disamping itu, data dokumentasi diperlukan untuk melengkapi data yang diperoleh berupa foto dokumen supervisi dan perangkat pembelajaran guru (RPP) yang telah di verifikasi kepala sekolah dan di tandatangani oleh kepala sekolah, dan kesemua dokumentasi ini akan dikumpulkan untuk dianalisa demi kelengkapan data penelitian.

Penelitian ini tidaak menggunakan system analisis uji statistic akan tetapi menggunakan analisis deskriptif dan komperatif dengan menggunakan matrik dan grafik. Instrumen penelitian ini dilakukan dengan menggunakan:1)Lembar pengamatan.Untuk lembar pengamatan kepala sekolah cukup dengan mengamati perangkat pembelajaran guru yang dibuat, penentuan metode, media yang cocok dengan pokok bahasannya, strategi pembelajarannya.

Untuk skala penilaian kinerja guru saat memberikan pembelajaran di kelas dengan menggunakan Instrumen penilaian kemampuan guru dalam pengembangan silabus, instrument penilaian kemampuan guru dalam menyusun rencana pembelajaran dan instrument penilaian kemampuan guru dalam penyajian pembelajaran.

Untuk angket dapat dilakukan kepala sekolah berupa pembinaan saat akan melaksanakan supervisi dan saat setelah pelaksanaan supervisi sebagai bahan pembinaan oleh kepala sekolah kepada guru dan dianalisis kembali apakah akan di lakukan supervisi kedua atau ketiga dan seterusnya dan yang terakhir sebagai bahan tindak lanjut hasil supervisi.

\section{HASIL PENELITIAN DAN PEMBAHASAN Hasil Penelitian}

Suharsimi Arikunto, Suhardjono, Supardi (2014: 83) menjelaskan pada bagian hasil penelitian dan pembahasan, menyajikan uraian masing-masing siklus dengan data lengkap mulai dari perencanaan, pelaksanaan, pengamatan, dan refleksi yang berisi penjelasan tentang aspek keberhasilan dan kelemahan yang terjadi, kemukakan grafik dan tabel secara optimal, hasil analisis data yang menunjukkan perubahan yang terjadi disertai pembahasan secara sistematis dan jelas 


\section{Siklus I}

Rencana Tindakan I. Untuk itu peneliti menyusun perencanan seperti apa yang disampaikan berikut ini:1)Merencanakan pembelajaran yang mampu membangkitkan keinginan siswa untuk ikut berpartisipasi 2)Merencanakan pembelajaran yang membuat siswa giat bertanya3)Merencanakan alat pembelajaran yang menarik minat siswa 4).Merencanakan materi ajar dari yang mudah ke yang lebih sulit 5)Merencanakan agar menjelaskan materi tidak terlalu cepat sehingga peserta didik gampang menerimanya

Pelaksanaan Tindakan I. Pelaksanaan yang baik dituntut agar nyambung dengan perencanananya. Dengan demikian peneliti melihat apa yang telah direncanakan terlebihdahulu selanjutnya melaksanakan penelitian ini dengan:1)Memperhatikan kekurangan-kekurangan sebelumnya, dengan giat memperbaiki kekurangan-kekurangan yang sudah ada dalam catatan pelaksanaan pembelajaran sesuai perencanan yang sudah dibuat 2)Menyampaikan bahan-bahan lain pendukung pembelajaran pada siswa agar materi dapat dibaca dari berbagai sumber.3)Mencatat aktivitas siswa di buku nilai 4.)Mendorong inisiatif peserta didik 5.Bergiat menumbuhkan partisipasi peserta didik

Observasi/Pengamatan Siklus I Pelaksanaan observasi atau pengumpulan data dilakukan dengan cara :1)Dalam melakukan observasi,peneliti menggunakan jenis instrumen yang telah disusun sebelumnya dalam RPP 2)Melakukan pemeriksaan hasil tes yang dilakukan siswa secara seksama untuk mendapatkan nilai yang diharapkan. 3.)Melakukan bimbingan secara individu yang lebih intensif kepada siswa yang mencapai nilai di bawah KKM serta memberikan motivasi untuk membangkitkan semangat belajar siswa 4.)Menjelaskan tentang tes yang akan diberikan.5.)Melaskanakan tes dengan mengikuti aturan-aturan dari standar penilaian.

Refleksi Siklus I. Refleksi merupakan kajian secara menyeluruh tindakan yang telah dilakukan berdasarkan data yang telah terkumpul, kemudian dilakukan evaluasi guna menyempurnakan tindakan.Refleksi menyangkut analisis, sintesis, dan penilaian terhadap hasil pengamatan atas tindakan yang dilakukan (Hopkin, 1993 dalam Suharsimi Arikunto, Suhardjono, Supardi, 2006: 80).

Melaksanakan penelitian setelah direncanakan, dilaksanakan dan diobservasi pada akhirnya sampai pada refleksi. Pada bagian refleksi peneliti melakukan hal-hal berikut 1.Ratarata (mean) Menyampaikan cara memperoleh sesuatu adalah kegiatan menjelaskan bahwa sesuatu itu diperoleh dengan cara tertentu. Untuk itu cara memperoleh nilai rata-rata dihitung dengan

Dalam hal ini untuk mencari median, langkah-langkah yang dilakukan adalah:mengurut data/nilai siswa dari yang terkecil sampai terbesar. Setelah diurut apabila jumlah data ganjil maka mediannya adalah data yang ditengah.Kalau jumlahnya genap maka dua data yang di tengah dijumlahkan dibagi 2 (dua).Untuk median yang diperoleh dari data siklus I dengan menggunakan cara tersebut

Modus (angka yang paling banyak/paling sering muncul)

Perhitungan untuk menentukan modus tidak sulit karena modus hanyalah angka yang terbanyak yang ada dari deretan angka yang diperoleh dari hasil penelitian.1.Untuk persiapan penyajian dalam bentuk grafik maka hal-hal berikut dihitung terlebih dahulu.

Banyak kelas $(\mathrm{K})=1+3,3 \times \log (\mathrm{N})$

$=1+3,3 \times \log 20$

$=1+3,3 \times 1,30$.

$=1+4,29=5,29 \rightarrow 6$

Rentang kelas $(\mathrm{r})=$ skor maksimum - skor minimum

$=92-60$

$=32$

Panjang kelas interval (i) $=\frac{r}{K}=\frac{32}{6}=5,33 \rightarrow 6$

Kekurangan-kekurangan / kelemahankelemahan yang ada dari pelaksanaan tindakan siklus I adalah:1).Metode yang dipakai mengajar masih lebih banyak didominasi oleh ceramah sehinga materi belum maksimal dalam penyerapannya2.)Diperlukan dukungan orang tua agar ikut mengarahkan anak-anaknya untuk lebih giat belajar.3) Pendekatan pembelajaran belum mampu membuat siswa untuk aktif belajar.4.)Penggunaan variasi metode pembelajaran belum maksimal 5).Banyak peserta didik duduk manis namun perhatian mereka tidak maksimal dalam pembelajaran.

Sedangkan kelebihan yang ditemukan pada pelaksanaan tindakan siklus I adalah:1).Peserta didik dapat merasakan perbedaan cara guru melaksanakan proses pembelajaran pada saat sebelum tindakan dilakukan dan setelah tindakan diberikan.2)Proses belajar mengajar dapat dilakukan dengan perencanaan yang sudah matang

\section{Siklus II}

Rencana Tindakan II. Sebelum melaksanakan suatu penelitian sudah pasti ada sebuah perencanaan yang baik. Untuk itu peneliti membuat perencanaan seperti: 1)Melakukan pengecekan mengenai jadwal pelaksanaan penelitian yang telah direncakan.2)Merencanakan pembimbingan yang bervariasi 3)Merencanakan pembimbingan yang menyenangkan 
4)Merencanakan pembelajaran yang menyenangkan.5)Merencanakan pembelajaran yang membangkitkan minat belajar

Pelaksanaan Tindakan II. Peneliti melaksanakan penelitian ini dengan Menjelaskan tujuan pembelajaran serta cakupan materi yang akan diajar ,Menciptakan suasana belajar yang nyaman ,Mengatur tempat duduk yang rapi ,Memotivasi agar siswa giat belajar bekerjas ,Mencek kemampuan awal siswa menggunakan beberapa pertanyaan

Refleksi Siklus II. Peneliti mencoba memaparkan hasil dan keberhasilan yang diperoleh dalam sebuah refleksi berikut ini. Refleksi merupakan kajian secara menyeluruh tindakan yang telah dilakukan berdasarkan data yang telah terkumpul, kemudian dilakukan evaluasi guna menyempurnakan tindakan.Refleksi menyangkut analisis, sintesis, dan penilaian terhadap hasil pengamatan atas tindakan yang dilakukan (Hopkin, 1993 dalam Suharsimi Arikunto, Suhardjono, Supardi, 2006: 80).

Rata-rata (mean)

Untuk perhitungan nilai rata-rata dicari dengan:

$\frac{\text { Jumlah nilai }}{\text { Jumlah siswa }}=\frac{1548 \text {. }}{20}=77,4$

Perhitungan untuk mendapatkan nilai tengah (median) adalah mengurut data/nilai siswa dari yang terkecil sampai terbesar. Setelah diurut apabila jumlah data ganjil maka mediannya adalah data yang ditengah.Kalau jumlahnya genap maka dua data yang di tengah dijumlahkan dibagi 2 (dua). Untuk median yang diperoleh dari data siklus II dengan menggunakan cara tersebut

Angka yang paling banyak muncul dalam data yang sudah dihasilkan merupakan modus dari data tersebut.1.Untuk persiapan penyajian dalam bentuk grafik maka hal-hal berikut dihitung terlebih dahulu.

Banyak kelas $(\mathrm{K})=1+3,3 \times \log (\mathrm{N})$

$=1+3,3 \times \log 20$

$=1+3,3 \times 1,30$

$=1+4,29=5,29 \rightarrow 6$

Rentang kelas $(\mathrm{r})=$ skor maksimum - skor minimum

$=98-65$

$=33$

Panjang kelas interval (i) $=\frac{r}{K}=\frac{33}{6}=5,5 \rightarrow 6$

Kekurangan-kekurangan / kelemahankelemahan yang ada dari pelaksanaan tindakan siklus II adalah 1)Terlihat jelas keaktifan siswa namun dari keaktifan tersebut ternyata membuat kelas sedikit gaduh dan sedikit ribut.2)Pengaruh teman-teman siswa yang mendominasi untuk tidak belajar Sedangkan kelebihan yang ditemukan pada pelaksanaan tindakan siklus II adalah:1)Siswa sudah terlihat lebih aktif tidak apatis dan lebih berminat dalam mengikuti proses belajar mengajar karena mereka sudah diupayakan untuk menemukan sendiri isi materi.2)Suatu kebanggaan terjadi pada diri guru akibat prestasi belajar siswa mampu ditingkatkan 3)Kecepatan peningkatan prestasi peserta didik dalam menguasai materi mampu lebih dioptimalkan.4)Peserta didik dapat merasakan perbedaan cara guru melaksanakan proses pembelajaran pada saat sebelum tindakan dilakukan dan setelah tindakan diberikan 5)Model ini mampu membuat guru tidak menyajikan pembelajaran secara bertele-tele seperti yang dilakukan sebelumnya.

\section{HASIL DAN PEMBAHASAN PENELITIAN Hasil yang diperoleh siklus I}

Sesuai peroleh data awal yang amat rendah yang belum sesuai dengan harapan dan tuntutan indikator keberhasilan penelitian akibat hal-hal yang sudah diupayakan pada latar belakang masalah, maka pada siklus I diupayakan perbaikan dengan memilih Supervisi akademik kepala sekolah sebagai upaya meningkatkan kinerja guru-guru SDN 004 Toapaya dalam pembelajaran di kelas semester 2 tahun pelajaran 2019/2020.

Model ini diupayakan pelaksanaannya di lapangan secara maksimal dengan mengikuti teori-teori yang ada. Kendala yang ada adalah pada diri guru yang berlum terbiasa untuk melaksanakan dengan model yang baru ini dan masih terlintas pada pikiran bahwa tugas guru adalah mengajar dan belum betul-betul dimengerti bahwa sesuai aturan Permen yang baru tugas guru adalah membelajarkan. Kebiasaan ini masih muncul dan mendominasi pembelajaran pada siklus I. Peneliti pada siklus I ini masih tetap berdiri di depan kelas memperlihatkan diri bahwa kegiatan lebih pada mengajar. Hal ini akhirnya dipecahkan dengan kembali berdiskusi dengan guru-guru, bertanya jawab baik pada saat pertemuan awal maupun pada saat dilakukan pertemuan balikan.

Peneliti giat melakukan diskusi, memberi pengertian-pengertian pada siswa dalam upaya menstimulir kegiatan yang dilakukan demi adanya perbaikan. Setelah giat dilakukan upaya untuk perbaikan akhirnya pada siklus I ini nilai siswa dapat meningkat walaupun belum sesuai harapan sesuai usulan keberhasilan penelitian. Kemampuan siswa awal dengan nilai rata-rata 50, akhirnya pada siklus I ini dapat ditingkatkan menjadi rata-rata 71 dengan ketuntasan belajar sebesar $0,35 \%$. kekurangan-kekurangan yang ada adalah masih terasa dominasi guru dalam pembelajaran, siswa belum giat bekerja, bertanya, berargumentasi, alat peraga/media belum mampu dioperasikan secara maksimal. 


\section{Hasil yang diperoleh dari siklus II}

Upaya yang lebih giat yang bisa peneliti laksanakan pada siklus yang kedua ini berpenekanan pada perbaikan-perbaikan dari kekurangan-kekurangan yang ada pada diri siswa maupun pada diri guru. Semua kekurangan pada siklus I yang sudah disampaikan menjadi acuan bagi peneliti untuk melakukan perbaikan. Perbaikan ini banyak dilakukan seperti membuat perencanaan pembelajaran yang lebih baik sebelum mereka masuk kelas. Pada saat melaksanakan proses pembelajaran bimbingan terus diupayakan diberi penekanan agar peserta didik merubah cara yang mereka belajar selama ini yaitu giat bekerja, giat mencari tahu, giat mengoptimalkan waktu pembelajaran untuk dapat menguasai materi yang diberikan.

Jadi guru tidak diharapkan untuk menceramahkan materi, guru tidak diharapkan menghabiskan waktunya untuk berdiri di depan kelas dan ngomong a, b, c, terus menerus mendominasi kelas. Yang dituntut adalah lebih $60 \%$ waktu digunakan oleh siswa untuk memperoleh pengalaman belajar, jadi guru boleh duduk di bangku guru dan tidak harus terus menerus berdiri ngomong ini, ngomong itu sampai habis waktu pembelajaran tetap juga berdiri. Pada pelaksanaan pembelajaran di siklus ini, bimbingan diupayakan lebih maksimal, arahan-arahan diberikan, tugas-tugas diberikan yang lebih menantang, giat bertanya terhadap apa yang belum mampu dikuasai, mengupayakan pembelajaran yang menyenangkan, yang interaktif, inspiratif serta memberi ruang yang banyak bagi peserta didik untuk berkreasi, menyalurkan bakat serta memupuk keberhasilan siswa untuk berargumentasi, bentukan pendapat semua ini diupayakan dalam upaya memperbaiki kekurangan-kekurangan yang ada selama siklus I.

Disamping itu peserta didik juga diminta untuk memperhatikan waktu dan tidak membuang-buang waktu pembelajaran. Diskusi yang matang arahan-arahan, bimbinganbimbingan yang dilakukan ternyata mampu menghasilkan peningkatan yang cukup signifikan. Dari rata-rata siklus I adalah 71 pada siklus yang ke II ini naik menjadi 75 Keberhasilan ini tidak terlepas dari upaya yang sungguh-sungguh, upaya yang maksimal yang dapat ditujukan untuk peningkatan mutu pendidikan. Dari hasil tersebut, rumusan masalah disampaikan maupun dijawab, begitu juga tujuan penelitian mampu diupayakan.

\section{SIMPULAN DAN SARAN \\ Simpulan}

Setelah mengadakan observasi selama 2 siklus maka dapat disimpulkan sebagai berikut 1) Pengetahuan guru tentang kompetensi guru dalam mengajar dan mengelola kelas harus dimiliki setiap guru sebagai bekal menjadi guru yang profesional; 2)Mengajar adalah sebuah proses yang harus diawali dengan persiapan mengajar yang matang, untuk menciptakan hasil yang baik dan sesuai dengan yang diharpakan pada dunia pendidikan; 3)Pemilihan metode dan media yang tepat akan sangat membantu keberhasilan pembelajaran; 4)Penguasaan materi adalah hal yang sangat penting untuk proses pembelajaran yang efektif sehingga mampu mencapai hasil yang maksimal; 5)Guru yang profesional adalah guru yang menguasai tupoksinya dengan baik serta dapat melaksanakan 4 kompetensi guru.

\section{Saran}

Peneliti menyarankan hal-hal sebagai berikut: 1)Sebaiknya guru selalu mempelajari perkembangan-perkembangan dalam dunia pendidikan; 2)Pembelajaran yang akan dilaksanakan hendaknya diawali dengan menyusun Rencana yang sesuai dengan aturan yang berlaku; 3)Dalam mengajar hendaknya menggunakan strategi pembelajaran dan media atau alat peraga yang dapat menumbuhkan semangat siswa dalam menerima materi; 4).Guru hendaknya selalu mencari inovasi untuk mengembangkan sistem pembelajaran untuk memperoleh mutu pendidikan yang maksimal

\section{DAFTAR PUSTAKA}

Masaong, Abd. Kadim. 2012. Supervisi Pembelajaran dan Pengembangan Kapasitas Guru. Bandung: Alfabrta.

Nadhirin. 2009. Supervisi Pendidikan Integratif Berbasis Budaya. Yogyakarta: Idea Press.

Purwanto, Ngalim. 2014. Administrasi dan Supervisi Pendidikan. Bandung: PT Remaja Rosdakarya.

Sagala, Syaiful. 2000. Administrasi Pendidikan Kontemporer. Bandung: CV Alfabeta.

Sahertian, Piet A. 2000. Konsep Dasar \& Taknik Supervisi Pendidikan dalam Rangka Pengembangan Sumber Daya Manusia. Jakarta: PT Rineka Cipta.

B.Uno, Hamzah. 2008. Profesi Kependidikan Problema Solusi dan Reformasi Pendidikan. Jakarta: PT. Bumi Aksara. 